\title{
Hippocampal overexpression of mutant creb blocks long-term, but not short-term memory for a socially transmitted food preference
}

\author{
Jennifer J. Brightwell, ${ }^{1}$ Clayton A. Smith, ${ }^{1}$ Renee A. Countryman, ${ }^{2}$ Rachael L. Neve, ${ }^{3}$ \\ and Paul J. Colombo ${ }^{1,2,4}$ \\ ${ }^{1}$ Neuroscience Program and ${ }^{2}$ Department of Psychology, Tulane University, New Orleans, Louisiana 70118, USA; ${ }^{3}$ Department of \\ Genetics, Harvard Medical School, McLean Hospital, Belmont, Massachusetts 02178, USA
}

Phosphorylation of the transcription factor CREB on Serl33 is implicated in the establishment of long-term memory for hippocampus-dependent tasks, including spatial learning and contextual fear conditioning. We reported previously that training on a hippocampus-dependent social transmission of food preference (STFP) task increases CREB phosphorylation in the hippocampus of trained rats in comparisons with controls. In the current study, we tested the hypothesis that CREB function is necessary for long-term memory for STFP using herpes simplex viral (HSV) vector-mediated gene transfer. Rats received intrahippocampal infusions of HSV-mCREB (a mutant form of CREB, in which Serl33 has been replaced with Ala), HSV-LacZ, or saline, and were trained 3 d later. Rats were tested for food preference (demonstrated vs. novel foods) immediately (short-term test) and $11 \mathrm{~d}$ (long-term test) after training. Rats in all treatment groups showed a significant preference for the demonstrated food at the short-term memory test. At the long-term memory test, however, the percentage of demonstrated food eaten by mCREB-treated rats was significantly less than that eaten by the LacZ- or saline-treated rats. Quantitative Western blotting confirmed that mCREB-infused rats had significantly more hippocampal CREB protein than controls during training. The present results show that hippocampal CREB function is necessary for long-term, but not short-term memory for STFP.

The social transmission of food preferences task assesses social olfactory and paired associate learning (Sutherland and Rudy 1989) that is both hippocampus-dependent and nonspatial (Winocur 1990; Bunsey and Eichenbaum 1995; Winocur et al. 2001; Alvarez et al. 2002). Galef and Wigmore (1983) found that a "subject" rat that was allowed to interact with a "demonstrator" rat that had recently eaten a flavored food was more likely to eat that food over another when given a choice between the two. Research using lesion techniques has revealed that the hippocampal region is necessary for formation of socially transmitted food preferences. Lesions prior to training impair long-term memory, while leaving short-term memory intact (Winocur 1990; Bunsey and Eichenbaum 1995; Winocur et al. 2001; but, see Burton et al. 2000) whereas post-training lesions produce temporally graded retrograde amnesia (Winocur 1990; Winocur et al. 2001), consistent with the hypothesis that the hippocampus mediates memory consolidation (Squire 1992).

Although the hippocampus is necessary for acquisition of socially transmitted food preferences, little is known about the neural mechanisms underlying this type of learning. Consolidation of short- to long-term memory requires protein synthesis and gene transcription, and transcriptional regulation has been examined as a potential mediator of mnemonic processes. cAMP response element-binding protein (CREB) is a constitutive transcription factor implicated in the consolidation of long-term memory (Dash et al. 1990; Bourtchuladze et al. 1994; Yin et al. 1994; Bartsch et al. 1995; Impey et al. 1998). Transcriptional regulation by CREB is dependent on CREB activation through phosphorylation of Ser133 (Gonzalez and Montminy 1989),

\section{${ }^{4}$ Corresponding author.}

E-mail pcolomb@tulane.edu; fax (504) 862-8774.

Article and publication are at http://www.learnmem.org/cgi/doi/10.1101/ Im.85005. which allows CREB to recruit CREB-binding protein (CBP), a molecule that links CREB to some components of the basal transcription machinery (Kwok et al. 1994). Experiments in which CREB is deleted or blocked have produced impairments in water-maze learning (Bourtchuladze et al. 1994; Gass et al. 1998; but, see also Graves et al. 2002), fear-potentiated startle (Falls et al. 2000), cued and contextual fear conditioning (Kida et al. 2002), as well as social transmission of food preferences (Kogan et al. 1997). Inhibition of CREB by administration of antisense in the hippocampus impairs long-term, but not short-term, spatial memory for the Morris water maze (Guzowski and McGaugh 1997). Administration of CREB antisense in the amygdala impairs longterm memory for conditioned taste aversion (Lamprecht et al. 1997), whereas CREB antisense administration in the olfactory bulb blocks long-term memory for olfactory aversive learning (Zhang et al. 2003). In addition, augmenting CREB levels in the basolateral amygdala facilitates long-term memory for fear conditioning (Josselyn et al. 2001).

Long-term memory is also associated with learning-induced changes in CREB activity. For example, increases in hippocampal-phosphorylated CREB are associated with inhibitory avoidance training (Bernabeu et al. 1997; Impey et al. 1998; Taubenfeld et al. 2001), contextual fear conditioning (Stanciu et al. 2001), spatial memory in the radial arm maze (Mizuno et al. 2002), and transient synapse formation following avoidance learning ( $\mathrm{O}^{\prime}$ Connell et al. 2000). Place and response learning in the cross maze are associated with sustained CREB phosphorylation in the hippocampus and neostriatum, respectively (Colombo et al. 2003). In addition, we reported increases in learninginduced CREB phosphorylation in the hippocampus following acquisition and recall of socially transmitted food preferences (Countryman et al. 2005). In that case, the increase was found in both the dorsal and ventral hippocampus, but CREB was activated most strongly in the ventral hippocampus, an area regu- 
lating social and ingestive behaviors (Kohler et al. 1985; Petrovitch et al. 2001).

The present study was designed to test whether or not CREB function in the hippocampus is necessary for long-term memory for a socially transmitted food preference. Viral vector-mediated gene transfer was used to inhibit CREB activity pretraining in both the dorsal and ventral hippocampus by overexpressing a mutant form of CREB (HSV-mCREB) in which Ser133 was replaced with Alanine. Although mCREB cannot be phosphorylated, it can bind to the cAMP response element in the promoter region, competing with endogenous CREB, and acting as a highly selective competitive antagonist (Carlezon Jr. et al. 1997, 1998; Josselyn et al. 2001). Rats were trained on the STFP task $3 \mathrm{~d}$ after infusion, when transgene levels were maximal (Barrot et al. 2002), tested for short-term memory immediately afterward, and tested for long-term memory $11 \mathrm{~d}$ later.

\section{Results}

Figure 1 shows that naive rats do not show a significant preference for any of the three flavored foods used in the present experiment $\left[F_{(2,12)}=2.82, P=0.099\right]$.

\section{Blockade of CREB function impairs long-term, but not short-term memory for a socially transmitted food preference}

The present behavioral results indicate that long-term, but not short-term memory is impaired following pretraining inhibition of CREB function in the hippocampus. Repeated measures ANOVA revealed a significant effect of treatment $\left[F_{(2,30)}=5.98\right.$, $P=0.006]$, delay $\left[F_{(1,30)}=20.05, P<0.001\right]$, and an interaction between treatment and delay $\left[F_{(2,30)}=5.54, P=0.008\right]$. Analysis of the interaction showed that rats receiving hippocampal infusions of HSV-mCREB ate significantly more of the demonstrated food during the short-term test than during the long-term test $(P<0.001)$. For the short-term test, one-way ANOVA showed no difference in the percent of demonstrated food eaten between rats receiving infusions of HSV-mCREB, HSV-LacZ, or saline $\left[F_{(2,30)}=0.79, P=0.463\right]$. At the long-term test, however, a difference was found between groups $\left[F_{(2,30)}=14.71, P<0.001\right]$ with HSV-mCREB-treated rats eating a significantly lower percent of the demonstrated food than HSV-LacZ- and saline-treated rats $\left(P^{\prime} \mathrm{s}<0.001\right)$, while HSV-LacZ- and saline-treated rats did not differ in the percentage of demonstrated food eaten $(P=0.217)$ (see Fig. 2). Individual student's $t$-tests (two-tailed) were performed at both the short- and long-term memory time points in order to compare the percentage of demonstrated food eaten against chance level performance (50\%). All three groups ate greater than chance levels of the demonstrated food immediately after training as predicted $\left[t_{(9)}=2.88, P<0.05, t_{(10)}=7.73, P<0.05\right.$,

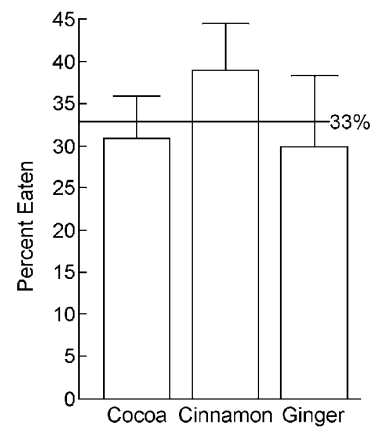

Figure 1. Naive rats do not show an innate preference for cocoa, cinnamon, or ginger-flavored rat chow at the concentrations tested.

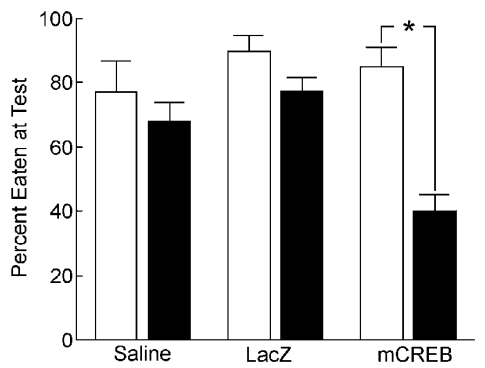

Figure 2. There was no difference among groups in the percent of demonstrated food eaten at the short-term memory test (white bars). Rats in the HSV-mCREB group ate significantly less of the demonstrated food than saline or Lac-Z controls at the long-term test (black bars).

$t_{(11)}=5.70, P<0.05$ for saline-, HSV-LacZ-, and HSV-mCREBtreated rats, respectively]. Eleven days after training, however, only controls (saline and HSV-LacZ) performed better than that predicted by chance $\left[t_{(9)}=3.00, P<0.05, t_{(10)}=6.68, P<0.05\right.$ for saline- and HSV-LacZ-treated rats, respectively]. The percentage of demonstrated food eaten by rats receiving infusions of HSVmCREB was not different from chance levels $\left[t_{(11)}=1.84\right.$, $P>0.05$ ] (see Fig. 2).

There was no difference between groups in the total amount of food eaten in grams (e.g., both demonstrated and novel foods) during either the short-term $\left[F_{(2,30)}=0.29, P=0.749\right]$ or longterm $\left[F_{(2,30)}=0.57, P=0.571\right]$ memory test (see Fig. 3 ). This demonstrates that infusion of HSV-mCREB does not alter the amount of food consumed during either short-term or long-term testing.

\section{HSV-LacZ infusion into the hippocampus causes expression of $\beta$-galactosidase}

Infusion of HSV-LacZ into the dorsal hippocampus (see Fig. 4A) and ventral hippocampus (see Fig. 4B) caused expression of $\beta$-galactosidase-positive cells $3 \mathrm{~d}$ later. The area surrounding the injection site was heavily stained with dark-blue cells with staining extending throughout the processes. The transgene expression covered an area of $\sim 1-1.5 \mathrm{~mm}$ in diameter in agreement with previous reports (Carlezon Jr. et al. 1998; Pliakas et al. 2001). In contrast, infusion of HSV-mCREB or saline into the dorsal or ventral hippocampus did not cause expression of $\beta$-galactosidase $3 \mathrm{~d}$ after infusion, thereby showing the specificity of the viralmediated transgene expression at this time point. Fourteen days following infusion, there was no expression of $\beta$-galactosidase in either the dorsal or ventral hippocampus (data not shown).

HSV-mCREB infusion into the hippocampus significantly increases total levels of hippocampal CREB

Quantitative Western blotting confirmed that expression of a mutant form of CREB (HSV-mCREB) in both the dorsal and ven-

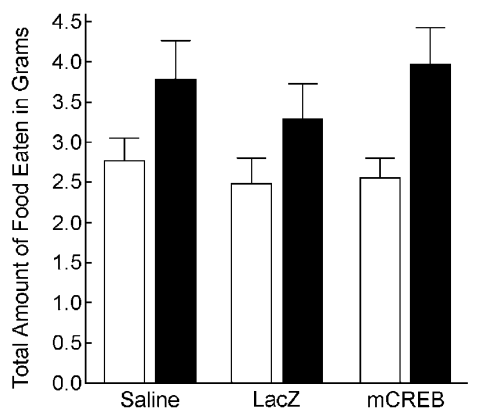

Figure 3. There was no difference among groups in the total amount of food eaten (both novel and demonstrated foods) at both the shortterm (white bars) and long-term memory tests (black bars). 


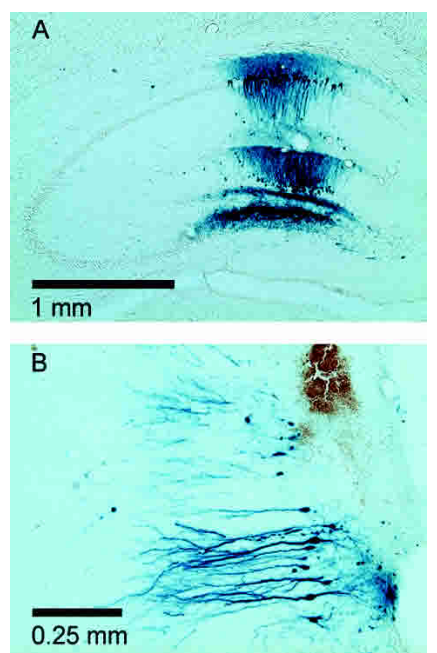

Figure 4. Expression of $\beta$-galactosidase $3 \mathrm{~d}$ after HSV-LacZ infusion into the dorsal $(A)$ and ventral $(B)$ hippocampus.

tral hippocampus caused a significant increase in total hippocampal CREB levels at the time of training in comparisons with HSV-LacZ- and saline-infused rats. Controls were sacrificed $3 \mathrm{~d}$ (e.g., time of training and short-term memory testing) or $14 \mathrm{~d}$ (e.g., time of long-term memory testing) after surgery. Three days following infusion of the viral vectors or saline, there was a significant difference among groups in total levels of CREB protein in the hippocampus $\left[F_{(2,6)}=32.79, P<0.001\right]$ (see Fig. 5). HSVmCREB-infused rats had more total hippocampal CREB protein in comparisons with rats infused with either HSV-LacZ or saline $\left(P^{\prime} \mathrm{s}<0.001\right)$. In contrast, total hippocampal CREB protein was not different between rats infused with either HSV-LacZ or saline $(P=0.458)$. There was no difference among groups in the amount of total hippocampal CREB levels $14 \mathrm{~d}$ following infusion $\left[F_{(2,6)}=1.65, P=0.268\right]$ (see Fig. 6). Total hippocampal CREB protein was measured in the above comparisons, because the antibody used bound to both mutant CREB and endogenous CREB.

\section{Discussion}

The results of the present experiment show that hippocampal CREB function is necessary for long-term, but not short-term memory for a socially transmitted food preference. In order to manipulate CREB function in the hippocampus specifically and temporally, viral vector-mediated gene transfer was used to over-

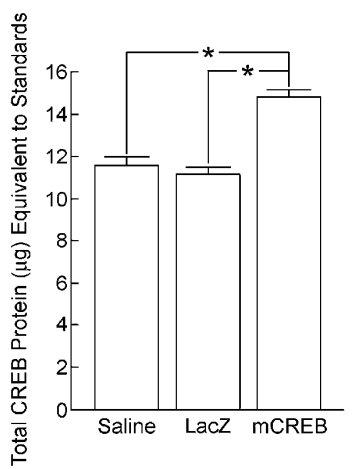

Figure 5. CREB protein levels $3 \mathrm{~d}$ after infusion. There was significantly more total CREB protein in the hippocampus of rats that received hippocampal HSV-mCREB infusions in comparisons with rats receiving hippocampal infusions of either saline or HSV-LacZ.

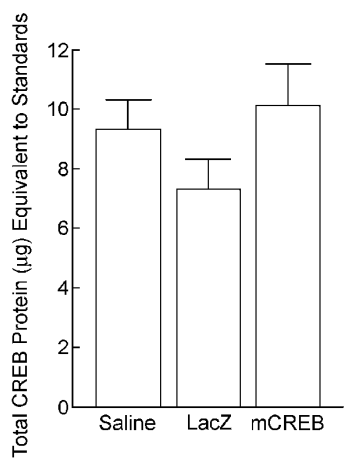

Figure 6. CREB protein levels $14 \mathrm{~d}$ after infusion. There was no difference in total hippocampal CREB levels among rats that received hippocampal infusions of saline, HSV-LacZ, or HSV-mCREB.

express a mutant form of CREB that cannot be phosphorylated, thus competing with endogenous CREB and suppressing gene expression (Carlezon Jr. et al. 1997, 1998; Josselyn et al. 2001). Food-preference training occurred $3 \mathrm{~d}$ after infusion, when levels of mCREB in the hippocampus were elevated (Carlezon Jr. et al. 1997, 1998; Pliakas et al. 2001; Barrot et al. 2002). Overexpression of mutant CREB did not affect food preference when rats were tested immediately after training. However, overexpression of mCREB during training did eliminate long-term memory for the food preference in comparisons with rats given either saline or HSV-LacZ, as shown by a test of food preference $11 \mathrm{~d}$ later. The memory impairment was specific to increased levels of mCREB, because overexpression of $\beta$-galactosidase, a control protein, did not alter preference for the demonstrated food when rats were tested $11 \mathrm{~d}$ later. Food consumption was comparable among rats receiving hippocampal infusions of saline, HSV-LacZ, or HSVmCREB during the short- and long-term tests; thus, motivation to eat was not affected by infusion of mutant CREB into the hippocampus.

Quantitative Western blotting confirmed that levels of total CREB protein were elevated in HSV-mCREB-treated rats in comparisons with saline- or HSV-LacZ-treated rats during training by $\sim 25 \%$. This increase most likely represents mutant CREB, because the antibody used does not differentiate between endogenous CREB and mutant CREB. LacZ staining showed that transgene infection ranged from 1 to $1.5 \mathrm{~mm}$ in diameter as shown in previous reports (Carlezon Jr. et al. 1998; Pliakas et al. 2001). Principal cells of area CA1 and dentate gyrus of the dorsal hippocampus were stained most densely, whereas area CA3 and dentate gyrus of the ventral hippocampus in the target region were stained less densely. We were unable to quantify the total number of infected cells in the hippocampus due to the density of staining, but others have reported $\sim 2000$ (Carlezon Jr. et al. 1998) to 4200 (Barrot et al. 2002) $\beta$-galactosidase-labeled cells visible in the area of injection on day 3 following infusion. While the total number of infected cells may be relatively small, the present results show that the number is sufficient to cause significant impairment of long-term memory for this task.

A benefit of using the social transmission of food preference task to measure long-term memory is that memory for a food preference has been shown to last for durations up to 3 mo (Clark et al. 2002). Our results are consistent with previous lesion research, in which the social transmission of food preference was used as a behavioral paradigm for studying nonspatial hippocampal-dependent memory. Intact short-term memory, but impaired long-term memory, has been reported on several occasions following pretraining lesions to the hippocampus (Winocur 1990; Bunsey and Eichenbaum 1995; Winocur et al. 2001; Clark et al.

\section{Learning \& Memory}

www.learnmem.org 
2002). Although lesion research has consistently found impairments in long-term memory using this task, whether or not impairments would be readily observable following selective manipulations in the intact brain has not been examined. We recently reported learning-induced CREB phosphorylation following training on the socially transmitted food preference task (Countryman et al. 2005). The present experiment establishes that CREB is not only associated with, but is necessary for formation of long-term memory for socially transmitted food preferences and follows previous studies implicating CREB in long-term memory formation (Dash et al. 1990; Bourtchuladze et al. 1994; Yin et al. 1994; Bartsch et al. 1995; Guzowski and McGaugh 1997; Impey et al. 1998; Kida et al. 2002; Zhang et al. 2003). Importantly, our results are consistent with reports that long-term memory for social recognition (Kogan et al. 2000) and social transmission of food preferences (Kogan et al. 1997) is impaired in CREB knock-out mice.

Herpes simplex viral vectors allow for temporal and localized manipulation of gene expression in animals that have developed normally. These vectors have been used only recently to examine the role of CREB in long-term memory. Expression of HSV-mCREB impairs long-term memory for odor-preference learning (Yuan et al. 2003), while overexpression of wild-type CREB using HSV vectors enhances long-term memory for fear conditioning (Josselyn et al. 2001). In addition, HSV-CREB vectors alter behavior and drug sensitivity when infused in reward pathways of the brain (Carlezon Jr. 1997, 1998; Pliakas et al. 2001; Barrot et al. 2002). HSV-CREB vectors, however, do not affect physical functioning as measured by locomotor activity in the open field (Barrot et al. 2002; Wallace et al. 2004) or elevated plus maze (Wallace et al. 2004), nor do they affect sensory functions such as visual sensory responsiveness (Liao et al. 2002; Mower et al. 2002) or taste perception as demonstrated by intact short-term memory among rats infused with HSV-mCREB in the present study.

Taken together, the results of the present study extend previous reports that CREB-mediated transcriptional regulation is a key neuronal component of memory consolidation in the hippocampus. Moreover, we demonstrate that selective manipulation of a signaling pathway in the intact hippocampus is sufficient to impair long-term memory for a nonspatial task.

\section{Materials and Methods}

\section{Subjects}

Eighty-nine male Long-Evans hooded rats (Charles River Laboratories) $\sim 250-300 \mathrm{~g}$ were housed individually in plastic-bottom cages with pine-chip bedding in a temperature-controlled room $\left(25^{\circ} \mathrm{C}\right)$ under a 12 -h light (7 a.m. -7 p.m.) /dark cycle with ad libitum access to food and water. Rats were handled extensively prior to training $(5 \mathrm{~min} / \mathrm{d} / 9 \mathrm{~d})$. All training was conducted during the light cycle. Rats were maintained on a 23-h food restriction schedule for $5 \mathrm{~d}$ prior to being housed in pairs and for $5 \mathrm{~d}$ prior to long-term memory testing.

\section{Viral-mediated gene transfer}

\section{Virus preparation}

The viral vectors (HSV-mCREB, and HSV-LacZ) were supplied by Dr. R.L. Neve (McLean Hospital, Harvard Medical School). Preparation of viruses was as described in Lim et al. (1996), Carlezon Jr. et al. (1997), Neve et al. (1997), and Carlezon Jr. et al. (1998). In brief, the cDNA's for a mutant form of CREB in which Ser133 was replaced by Ala (mCREB) (provided by Dr. E.J. Nestler), or LacZ were inserted into an HSV amplicon (HSV-PrpUC) and packaged using an IE2 deletion mutant $5 \mathrm{dl} 1.2$ (helper virus). The virus was purified using a sucrose gradient, pelleted, and resuspended in
$10 \%$ sucrose. The estimated titer of these recombinant viral stocks was $10^{8}$ infectious units/mL.

\section{Surgical procedure}

Surgery was performed according to procedures for aseptic techniques in survival surgery adapted from The Experimental Animal in Biomedical Research (Rollin and Kesel 1990). All surgical procedures were performed in a class II biohazard cabinet (Labconco, Fisher Scientific). Rats were anesthetized with a continuous supply of $1 \%-5 \%$ isoflurane gas and secured in a stereotaxic frame (Kopf Instruments). The infusion coordinates for the dorsal hippocampus were $(\mathrm{AP}=-3.3 \mathrm{~mm}, \mathrm{ML}= \pm 2.0 \mathrm{~mm}, \mathrm{DV}=-3.4 \mathrm{~mm})$ and for the ventral hippocampus were $(\mathrm{AP}=-5.6 \mathrm{~mm}$, $\mathrm{ML}= \pm 4.6 \mathrm{~mm}, \mathrm{DV}=-6.2 \mathrm{~mm}$ ). Bilateral injections of $2 \mu \mathrm{L}$ (HSV-mCREB, HSV-LacZ, or saline) were infused over $10 \mathrm{~min}$ at a rate of $0.2 \mu \mathrm{L} / \mathrm{min}$ through 28-gauge infusion needles (Plastics One) connected via polyethylene tubing to two $10-\mu \mathrm{L}$ Hamilton syringes driven by a multiple syringe infusion pump (Fisher Scientific). The infusion needles remained in place for $10 \mathrm{~min}$ following the infusion procedure to facilitate diffusion away from the needles. Studies using this infusion procedure have shown that transgene expression is restricted to an area $\sim 1.5 \mathrm{~mm}$ in diameter (Carlezon Jr. et al. 1998) and is specific to neurons (Carlezon Jr. et al. 2000; Pliakas et al. 2001; Barrot et al. 2002). The burr holes were sealed with bone wax and the incision closed, after which each rat was placed in a recovery box with a heat lamp overhead, and monitored while recovering from anesthesia. Animals were returned to the vivarium when they recovered from anesthesia and were ambulatory. All rats received $24 \mathrm{~h}$ of postoperative analgesics (buprenorphine, $0.02 \mathrm{mg} / \mathrm{kg}$ SQ BID).

\section{Behavioral training}

\section{Test of innate food preference}

In order to verify that rats did not have an innate food preference for any of the demonstrated foods, naive rats $(n=5)$ were put on a $23 \mathrm{~h}$ food restriction schedule for $5 \mathrm{~d}$. On the sixth day, the rats were placed individually in a plastic-bottom cage $(42 \times 24 \times 27$ $\mathrm{cm}$ ) with $\sim 12 \mathrm{~g}$ each of $2 \%$ cocoa, $1 \%$ cinnamon, and $1 \%$ gingerflavored rat chow in food cups placed equidistant from each other. Rats were allowed to eat for $1 \mathrm{~h}$. The difference among the percentage of cocoa, cinnamon, and ginger-flavored rat chow eaten was analyzed using ANOVA with significance set at $P<0.05$.

\section{Social transmission of food preferences}

The training procedures were adapted from those reported by Winocur (1990) and Winocur and Moscovitch (1999) and described previously (Countryman et al. 2005). The procedure was modified to accommodate surgery and the time-course of transgene expression. Experimental rats were randomly separated into Subject $(n=33)$ and Demonstrator $(n=33)$ conditions. One day before surgery, subjects and demonstrators were housed together in a plastic-bottom cage $(42 \times 24 \times 27 \mathrm{~cm})$ lined with sawdust bedding (Interaction). The rats were separated from physical contact by a wire mesh screen with openings of $\sim 1 \mathrm{~cm}$. The following day, subjects received surgery to infuse $2 \mu \mathrm{L}$ of HSV-mCREB $(n=12)$, HSV-LacZ $(n=11)$, or saline $(n=10)$ bilaterally into both the dorsal and ventral hippocampus, and afterward were placed back into the interaction cage. Rat dyads were left undisturbed for $2 \mathrm{~d}$ with ad libitum access to water and regular rat chow. All food was taken away from both the subjects and demonstrators $23 \mathrm{~h}$ before STFP training. On the third day following surgery, STFP training took place. Demonstrators were removed from the interaction cage and allowed $30 \mathrm{~min}$ to eat cocoaflavored rat chow ( $2 \%$ cocoa in ground rat chow). Demonstrators were then placed back in the interaction cage in order to interact with subjects through the wire mesh screen. After $30 \mathrm{~min}$, subjects were removed from the interaction cage and placed in a plastic-bottom cage $(42 \times 24 \times 27 \mathrm{~cm})$ for short-term memory testing. Two food cups were located at opposite ends of the cage, one containing $\sim 12 \mathrm{~g}$ of $2 \%$ cocoa-flavored rat chow and the 
other containing $\sim 12 \mathrm{~g}$ of $1 \%$ cinnamon-flavored rat chow. A $1-\mathrm{cm}$ plastic ledge was fixed to the middle of the cage in order to prevent scattered food from mixing. Subjects were given $1 \mathrm{~h}$ to eat, after which they were returned to their home cages for $10 \mathrm{~d}$. Subjects were put on a 23 -h food restriction schedule for $5 \mathrm{~d}$ prior to long-term memory testing. Long-term memory testing took place on the eleventh day following training (14 d following surgery). Subjects were taken out of their home cages and again placed in a plastic-bottom cage with $\sim 12 \mathrm{~g}$ of $2 \%$ cocoa-flavored rat chow at one end and 1\% ginger-flavored rat chow at the other. Subjects were again allowed to eat for $1 \mathrm{~h}$. Differences in the percent of demonstrated food eaten among groups were analyzed using ANOVA with significance set at $P<0.05$. Aposteriori LSD tests were used to test main effects.

\section{Histology}

Following behavioral testing, cannulae placements for the majority of rats in the subject condition $(n=24)$ were confirmed by cresyl violet staining. The remaining rats $(n=9)$ were included in Western blot analysis of CREB protein levels. For these rats, cannulae placement was confirmed by visual inspection of the dissected hippocampi. All needle tracts fell within the target region, and no rats were excluded from statistical analyses on the basis of this examination.

\section{Tissue preparation}

\section{Western blot tissue preparation}

Dissection of the hippocampus was performed on a chilled glass stage. The tissue was weighed and homogenized in 5 vol of icecold $20 \mathrm{mM}$ Tris-HCL (pH 7.4) containing 0.25 M sucrose, $2 \mathrm{mM}$ EDTA, $10 \mathrm{mM}$ EGTA, $5 \mathrm{mM}$ dithiothreitol, $0.234 \mathrm{mM}$ leupeptin, $0.1 \%$ triton $\mathrm{X}-100$, and $1 \mathrm{mM}$ PMSF. A fraction of the total homogenate $(50 \mu \mathrm{L})$ was removed to measure total protein (Bradford 1976). The remaining homogenate was mixed (1:1) with $2 \times$ Laemlli sample buffer $(0.2 \mathrm{M}$ SDS, $20 \%$ glycerol, $10 \% \beta$-mercaptoethanol, $0.004 \%$ bromophenol blue, $1.5 \%$ Tris), boiled for 5 min, and stored at $-20^{\circ} \mathrm{C}$ until Western blot analysis.

\section{LacZ-staining tissue preparation}

Under anesthesia (ketamine [100 mg/kg body wgt.]/xylazine [7 $\mathrm{mg} / \mathrm{kg}$ body wgt.]), rats were perfused transcardially with $2 \%$ $\mathrm{NaNO}_{3} / 0.9 \%$ saline, followed by $4 \%$ paraformaldehyde/0.1 M phosphate buffer (PB). The brains were removed and placed in $4 \%$ paraformaldehyde for $3 \mathrm{~h}$, after which they were placed in a sucrose solution (20\% sucrose/1\% DMSO/0.1 M PB) overnight at $4^{\circ} \mathrm{C} ; 50-\mu \mathrm{m}$ sections were taken from the dorsal and ventral hippocampus using a freezing microtome and stored in cryoprotectant $(1.25 \%$ polyvinylpyrrolidone $/ 37.5 \%$ ethylene glycol/ $37.5 \%$ sucrose $/ 0.05 \mathrm{M} \mathrm{PB}$ ) at $-20^{\circ} \mathrm{C}$ until further use. Coronal sections were taken throughout the hippocampus $(-2.56$ to $-6.04 \mathrm{~mm}$ ) relative to Bregma (Paxinos and Watson 1998).

\section{Biochemical analyses}

\section{Western blot analysis}

Samples of whole-tissue homogenate from individual rats infused with HSV-mCREB, HSV-LacZ, or saline $3(n=9)$ or 14 $(n=9)$ d prior to dissection were normalized for total protein content by dilution with a 1:1 mixture of $2 \times$ sample buffer:running buffer. Normalized total homogenates $(25 \mu \mathrm{L})$ from both samples (15 $\mu \mathrm{g}$ total protein) and standards (homogenate from naive rats in a linear range from 7 to $18 \mu \mathrm{g}$ total protein) were resolved on $12 \%$ SDS-polyacrylamide gels and transferred electrophoretically overnight at $4^{\circ} \mathrm{C}$ to PVDF immobilon membranes (Millipore). PVDF membranes were probed with an antibody specific for CREB (CREB, 06-863, 1:750; Upstate Biotechnology Inc.). Membranes were incubated in $1^{\circ}$ antibody for $1.5 \mathrm{~h}$, followed by incubation $(1.5 \mathrm{~h})$ with $2^{\circ}$ antibody conjugated to horseradish peroxidase (1:10,000; Kierkegard \& Perry Laboratories). Before and after primary antibody incubation the membranes were washed $3 \times 5$ min in $0.1 \mathrm{M} \mathrm{PBS}(\mathrm{pH} 7.4)$ and blocked
$3 \times 5$ min in $0.1 \mathrm{M}$ PBS containing 5\% nonfat dry milk and $0.03 \%$ Tween-20. Following the secondary antibody incubation, the membranes were washed $15 \times 6 \mathrm{~min}$ in $0.1 \%$ Tween-20/0.1 M PBS. All incubations and washes were conducted at room temperature on a slow rocker. The immunoreactive bands were visualized with the ECL-enhanced chemiluminescence kit (Amersham Pharmacia Biotech) and filmed using Kodak Scientific imaging X-OMAT film.

\section{Confirmation of $\beta$-galactosidase transgene expression}

Sections $(50 \mu \mathrm{M})$ from rats infused with HSV-mCREB, HSV-LacZ, or saline $3(n=9)$ or $14(n=9)$ d prior to dissection were probed overnight for $\beta$-galactosidase by incubation in $5 \mathrm{mM}$ potassium ferrocyanide, $4.8 \mathrm{mM}$ potassium ferricyanide, $20 \mathrm{mM} \mathrm{MgCl}_{2}, 0.1$ $\mathrm{M}$ PBS, and 5-bromo-4-chloro-3-indolyl- $\beta$-D-galactopyramosidase $(0.2 \mathrm{mg} / \mathrm{mL}$; Boehringer Mannheim) (Lim et al. 1996; Carlezon Jr. et al. 1997, 1998; Neve et al. 1997). Expression of $\beta$-galactosidase was confirmed by visual inspection of the area around the injection site (Carlezon Jr. et al. 1998).

\section{Image analysis}

\section{Western blot analysis}

Densitometric analysis of the autoradiograms was performed using Flashpoint 128 Framegrabber and Scion Image (NIH Image software equivalent for the PC). An integrated function of optical density $\mathrm{X}$ band area was taken as the measure of protein in each sample. Relative amounts of CREB were determined by regression analysis from a standard curve prepared from known concentrations of total protein $(7-18 \mu \mathrm{g})$ from naive animals (Colombo et al. 1997). Differences in total protein levels among groups were analyzed using ANOVA with significance set at $P<0.05$. Aposteriori LSD tests were used to test main effects.

\section{Acknowledgments}

This work was supported by IBN-0133734 to P.J.C.

\section{References}

Alvarez, P., Wendelken, L., and Eichenbaum, H. 2002. Hippocampal formation lesions impair performance in an odor-odor association task independently of spatial context. Neurobiol. Learn. Mem. 78: $470-476$.

Barrot, M., Olivier, J.D., Perrotti, L.I., DiLeone, R.J., Berton, O., Eisch, A.J., Impey, S., Storm, D.R., Neve, R.L., Yin, J.C., et al. 2002. CREB activity in the nucleus accumbens shell controls gating of behavioral responses to emotional stimuli. Proc. Natl. Acad. Sci. 99: 11435-11440.

Bartsch, D., Ghirardi, M., Skehel, P.A., Karl, K.A., Herder, S.P., Chen, M., Bailey, C.H., and Kandel, E.R. 1995. Aplysia CREB2 represses long-term facilitation: Relief of repression converts transient facilitation into long-term functional and structural change. Cell 83: 979-992.

Bernabeu, R., Bevilaqua, L., Ardenghi, P., Bromberg, E., Schmitz, P. Bianchin, M., Izquierdo, I., and Medina, J.H. 1997. Involvement of hippocampal cAMP/cAMP-dependent protein kinase signaling pathways in a late memory consolidation phase of aversely motivated learning in rats. Proc. Natl. Acad. Sci. 94: 7041-7046.

Bourtchuladze, R., Frenguelli, B., Blendy, J., Cioffi, D., Schutz, G., and Silva, A.J. 1994. Deficient long-term memory in mice with a targeted mutation of the cAMP-responsive element-binding protein. Cell 79: $59-68$

Bradford, M.M. 1976. A rapid and sensitive method for the quantification of microgram quantities of protein utilizing the principle of protein-dye binding. Anal. Biochem. 72: 248-254.

Bunsey, M. and Eichenbaum, H. 1995. Selective damage to the hippocampal region blocks long-term retention of a natural and nonspatial stimulus-stimulus association. Hippocampus 5: 546-556.

Burton, S., Murphy, D., Qureshi, U., Sutton, P., and O'Keefe, J. 2000. Combined lesions of hippocampus and subiculum do not produce deficits in a non-spatial social olfactory memory task. J. Neurosci. 20: $5468-5475$.

Carlezon Jr., W.A., Boundy, V.A., Haile, C.N., Lane, S.B., Kalb, R.G., Neve, R.L., and Nestler, E.J. 1997. Sensitization to morphine induced by viral-mediated gene transfer. Science 277: 812-814.

Carlezon Jr., W.A., Thome, J., Olson, V.G., Lane-Ladd, S.B., Brokin, E.S., Hiroi, N., Duman, R.S., Neve, R.L., and Nestler, E.J. 1998. Role of 
CREB in cocaine reward. Science 181: 2272-2274.

Carlezon Jr., W.A., Nestler, E.J., and Neve, R.L. 2000. Herpes simplex virus-mediated gene transfer as a tool for neuropsychiatric research Crit. Rev. Neurobiol. 14: 47-68.

Clark, R.E., Broadbent, N.J., Zola, S.M., and Squire, L.R. 2002. Anterograde amnesia and temporally graded retrograde amnesia for a nonspatial memory task after lesions of hippocampus and subiculum. J. Neurosci. 22: 4663-4669.

Colombo, P.J., Wetsel, W.C., and Gallagher, M. 1997. Spatial memory is related to hippocampal subcellular concentrations of calcium-dependent protein kinase $\mathrm{C}$ isoforms in young and aged rats. Proc. Natl. Acad. Sci. 94: 14195-14199.

Colombo, P.J., Brightwell, J.J., and Countryman, R.A. 2003. Cognitive strategy-specific increases in cAMP response element-binding protein and c-Fos in the hippocampus and dorsal striatum. J. Neurosci. 23: 3547-3554.

Countryman, R.A., Orlowski, J.D., Brightwell, J.J., Oskowitz, A.Z., and Colombo, P.J. 2005. CREB phosphorylation and c-fos expression in the hippocampus of rats during acquisition and recall of a socially transmitted food preference. Hippocampus 15: 56-67.

Dash, P.K., Hochner, B., and Kandel, E.R. 1990. Injection of the cAMP-responsive element into the nucleus of Aplysia sensory neurons blocks long-term facilitation. Nature 345: 718-721.

Falls, W.A., Kogan, J.H., Silva, A.J., Willott, J.F., Carlson, S., and Turner, J.G. 2000. Fear-potentiated startle, but not prepulse inhibition of startle, is impaired in CREB $\alpha \delta-/-$ mutant mice. Behav. Neurosci. 114: 998-1004.

Galef, B.G. and Wigmore, S.R. 1983. Transfer of information concerning distant foods: A laboratory investigation of the "information-centre" hypothesis. Anim. Beh. 31: 748-758.

Gass, P., Wolfer, D.P., Balschun, D., Rudolph, D., Frey, U., Lipp, H-P. and Schütz, G. 1998. Deficits in memory tasks of mice with CREB mutations depend on gene dosage. Learn. Mem. 5: 274-288.

Gonzalez, G.A. and Montminy, M.R. 1989. Cyclic AMP stimulates somatostatin gene transcription by phosphorylation of CREB at serine 133. Cell 59: 675-680.

Graves, L., Dalvi, A., Lucki, I., Blendy, J.A., and Abel, T. 2002. Behavioral analysis of CREB $\alpha \Delta$ mutation on a B6/129 F1 hybrid background. Hippocampus 12: 18-26.

Guzowski, J.F. and McGaugh, J.L. 1997. Antisense oligodeoxynucleotide-mediated disruption of hippocampal cAMP response element binding protein levels impairs consolidation of memory for water maze training. Proc. Natl. Acad. Sci. 94: $2693-2698$.

Impey, S., Smith, D.M., Obrietan, K., Donahue, R., Wade, C., and Storm, D.R. 1998. Stimulation of cAMP response element (CRE)-mediated transcription during contextual learning. Nat. Neurosci. 1: 595-601.

Josselyn, S.A., Shi, C., Carelzon Jr., W.A., Neve, R.L., Nestler, E.J., and Davis, M. 2001. Long-term memory is facilitated by cAMP response element-binding protein overexpression in the amygdala. J. Neurosci. 21: 2402-2412.

Kida, S., Josselyn, S.A., de Ortiz, S.P., Kogan, J.H., Chevere, I., Masushige, S., and Silva, A.J. 2002. CREB required for the stability of new and reactivated fear memories. Nat. Neurosci. 5: 348-355.

Kogan, J.H., Frankland, P.W., Blendy, J.A., Coblentz, J., Marowitz, Z., Schutz, G., and Silva, A.J. 1997. Spaced training induces normal long-term memory in CREB mutant mice. Curr. Biol. 7: 1-11.

Kogan, J.H., Frankland, P.W., and Silva, A.J. 2000. Long-term memory underlying hippocampus-dependent social recognition in mice. Hippocampus 10: $47-56$.

Kohler, C., Swanson, L.W., Hagland, L., and Wu, J.Y. 1985. The cytoarchitecture, histochemistry and projections of the tuberomammillary nucleus in the rat. Neuroscience 16: 85-110.

Kwok, R.P., Lundblad, J.R., Chrivia, J.C., Richards, J.P., Bachinger, H.P. Brennan, R.G., Roberts, S.G., Green, M.R., and Goodman, R.H. 1994. Nuclear protein CBP is a coactivator for the transcription factor CREB. Nature 370: 223-226.

Lamprecht, R., Hazvi, S., and Dudai, Y. 1997. cAMP response element-binding protein in the amygdala is required for long- but not short-term conditioned taste aversion memory. J. Neurosci. 17: $8443-8450$.

Liao, D.S., Mower, A.F., Neve, R.L., Sato-Bigbee, C., and Ramoa, A.S 2002. Different mechanisms for loss and recovery of binocularity in the visual cortex. J. Neurosci. 22: 9015-9023.

Lim, F., Hartley, D., Starr, P., Lang, P., Song, S., Yu, L., Wang, Y., and Geller, A.I. 1996. Generation of high-titer defective HSV-1 vectors using an 1E2 deletion mutant and quantitative study of expression in cultured cortical cells. Biotechniques 20: 460-469.

Mizuno, M., Yamada, K., Maekawa, N., Saito, K., Seishima, M., and Nabeshima, T. 2002. CREB phosphorylation as a molecular marker of memory processing in the hippocampus for spatial learning. Behav. Brain Res. 133: 135-141.

Mower, A.F., Liao, D.S., Nestler, E.J., Neve, R.L., and Ramoa, A.S. 2002. cAMP/Ca2+ response element-binding protein function is essential for ocular dominance plasticity. J. Neurosci. 22: 2237-2245.

Neve, R.L., Howe, J.R., Hong, S., and Kalb, R.G. 1997. Introduction of the glutamate receptor subunit 1 into motor neurons in vitro and in vivo using a recombinant herpes simplex virus. Neuroscience 79: $435-447$.

O'Connell, C., Gallagher, H.C., O'Malley, A., Bourke, M., and Regan, C.M. 2000. CREB phosphorylation coincides with transient synapse formation in the rat hippocampal dentate gyrus following avoidance learning. Neur. Plast. 7: 279-289.

Paxinos, G. and Watson, C. 1998. The rat brain in stereotaxic coordinates $4^{\text {th }}$ ed., Academic Press, San Diego, CA

Petrovitch, G.D., Canteras, N.S., and Swanson, L.W. 2001. Combinatorial amygdalar inputs to hippocampal domains and hypothalamic behavior systems. Brain Res. Brain Res. Rev. 38: $247-289$.

Pliakas, A.M., Carlson, R.R., Neve, R.L., Konradi, C., Nestler, E.J., and Carlezon Jr., W.A. 2001. Altered responsiveness to cocaine and increased immobility in the forced swim test associated with elevated cAMP response element-binding protein expression in nucleus accumbens. J. Neurosci. 21: 7397-7403.

Rollin, B. and Kesel, M.L. (eds.) 1990. The Experimental Animal in Biomedical Research, Vol. 1, CRC Press, Boca Raton, FL.

Squire, L.R. 1992. Memory and the hippocampus: A synthesis from findings with rats, monkeys, and humans. Psychol. Rev. 99: 195-231.

Stanciu, M., Radulovic, J., and Spiess, J. 2001. Phosphorylated cAMP response element binding protein in the mouse brain after fear conditioning: Relationship to Fos production. Mol. Brain Res. 94: $15-24$.

Sutherland, R.J. and Rudy, J.W. 1989. Configural association theory: The role of the hippocampal formation in learning, memory, and amnesia. Psychobiology 17: 129-144.

Taubenfeld, S.M., Wiig, K.A., Monti, B., Dolan, B., Pollonini, G., and Alberini, C.M. 2001. Fornix-dependent induction of hippocampal CCAAT enhancer-binding protein $\beta$ and $\delta$ co-localizes with phosphorylated cAMP response element-binding protein and accompanies long-term memory consolidation. J. Neurosci. 21: 84-91.

Wallace, T.L., Stellitano, K.E., Neve, R.L., and Duman, R.S. 2004. Effects of cyclic adenosine monophosphate response element binding protein overexpression in the basolateral amygdala on behavioral models of depression and anxiety. Biol. Psy. 56: 151-160.

Winocur, G. 1990. Anterograde and retrograde amnesia in rats with dorsal hippocampal or dorsomedial thalamic lesions. Behav. Brain Res. 38: 145-154.

Winocur, G. and Moscovitch, M. 1999. Anterograde and retrograde amnesia after lesions to frontal cortex in rats. J. Neurosci. 19: $9611-9617$.

Winocur, G., McDonald, R.M., and Moscovitch, M. 2001. Anterograde and retrograde amnesia in rats with large hippocampal lesions. Hippocampus 11: 18-26.

Yin, J.C.P., Wallach, J.S., Del Vecchio, M., Wilder, E.L., Zhou, H., Quinn, W.G., and Tully, T. 1994. Induction of a dominant negative CREB transgene specifically blocks long-term memory in Drosophila. Cell 79: 49-58.

Yuan, Q., Harley, C.W., Darby-King, A., Neve, R.L., and McLean, J.H. 2003. Early odor preference learning in the rat: Bidirectional effects of cAMP response element-binding protein (CREB) and mutant CREB support a causal role for phosphorylated CREB. J. Neurosci. 23: 4760-4765.

Zhang, J.J., Okutani, F., Inoue, S., and Kaba, H. 2003. Activation of the cyclic AMP response element-binding protein signaling pathway in the olfactory bulb is required for the acquisition of olfactory aversive learning in young rats. Neuroscience 117: 707-713.

Received August 4, 2004; accepted in revised form November 23, 2004. 


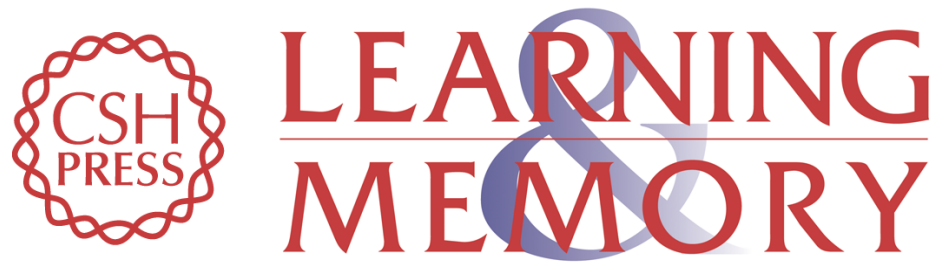

\section{Hippocampal overexpression of mutant creb blocks long-term, but not short-term memory for a socially transmitted food preference}

Jennifer J. Brightwell, Clayton A. Smith, Renee A. Countryman, et al.

Learn. Mem. 2005, 12:

Access the most recent version at doi:10.1101//m.85005

References This article cites 45 articles, 16 of which can be accessed free at:

http://learnmem.cshlp.org/content/12/1/12.full.html\#ref-list-1

License

Email Alerting Receive free email alerts when new articles cite this article - sign up in the box at the Service top right corner of the article or click here. 